UDC 37.018.43

JEL: I21, M21, M53

\section{Lidija Weis}

Doctor of Business

Administration,

Ljubljana School of Business,

Ljubljana, Slovenia

E-mail: lidija.weis@vspv.si

orcid.org/0000-0001-5193-5103

Received: February 03, 2021

Accepted: March 12, 2021

DOI:10.31520/2616-7107/2021.5.1-4

(C) Economics. Ecology. Socium, 2021

CC BY-NC 4.0 license

\section{THEORETICAL APPROACH TO E-LEARNING QUALITY}

Introduction. Over the past decade, as technology coupled with the increasingly frequent use of the internet have become the forefront of business and academia, e-learning has emerged on the global higher education stage as a leading means of gaining an education in Higher Education. Because internet-based learning is currently such a relevant topic, inter alia due to the occurrence of the pandemic, there is a dire need for the creation of a common language to proceed in a collectively positive direction regarding the development of a culture of excellence within e-learning. This paper provides a springboard to discuss the underlying issues and challenges related to quality of internet-based learning, including the need for right measuring, and understanding dimensions of elearning quality.

Aim and tasks. The quality of education needs to be addressed (measured and managed) comprehensively, which means that, in addition to pedagogical aspects, it is also necessary to address the market quality. Therefore, a distinction must be made between quality that meets specifications (standard quality) and quality that meets expectations. Therefore, the main aim of the article is to review the different definitions of quality in e-learning and the dimensions that must be included in measuring the quality of e-learning.

Results. Based on an extensive review of the literature on quality in e-learning, we conclude that the quality of elearning cannot be viewed only from the student's perspective, but from the point of view of all participants in the e-learning process. In addition to pedagogical aspects, organizational, economic, and legal aspects must also be considered. What dimensions are key to measuring quality in e-learning thus remains a question to be answered.

Conclusions. The quality of e-learning depends on many factors. Despite many discussions about quality and the search for appropriate dimensions of quality in e-learning, there is still no single evaluative standard. Because of this, effective qualitative metrics for e-learning are urgently required.

Keywords: E-learning, quality, higher education, ICT, management practices. 
УДК 37.018.43

JEL: I21, M21, M53

\section{Лідія Вайс}

Доктор економічних наук, професор,

Люблянська школа бізнесу, м. Любляна, Словенія orcid.org/0000-0001-5193-5103

Отримано: 3 Лютого, 2021

Прийнято: 12 Березня, 2021

DOI:10.31520/2616-7107/2021.5.1-4

(C) Економіка. Екологія. Соціум, 2021

CC BY-NC 4.0 ліцензія

\section{ТЕОРЕТИЧНИЙ ПІДХІД ДО ЯКІСТІ ДИСТАНЦІЙНОГО НАВЧАННЯ}

Вступ. Протягом останнього десятиліття, коли технології в поєднанні із дедалі частішим використанням Інтернету стали головними для бізнесу та наукових кіл, електронне навчання з'явилося у світовій вищій освіті як провідний засіб здобуття освіти у галузі вищої освіти. Оскільки в даний час навчання на основі Інтернету $є$ такою актуальною темою, в тому числі через появу пандемії, існує гостра необхідність у розвитку системи E-learning, яка рухатиметься в сукупному позитивному напрямку щодо розвитку культури та досконалості в межах електронного навчання. Стаття пропонує основу для обговорення основних питань та проблем, пов'язаних 3 якістю навчання в Інтернеті, включаючи необхідність у правильному вимірюванні та розумінні оцінки якості електронного навчання.

Мета i завдання. Якість освіти потребує комплексного вирішення (вимірювання та управління), а це означає, що, крім педагогічних аспектів, необхідно також звернути увагу на якість ринку. Тому слід розрізняти якість, що відповідає специфікаціям (стандартна якість), та якість, яка відповідає очікуванням. Отже, основною метою статті $є$ огляд різних визначень якості електронного навчання та вимірів, які необхідно враховувати при вимірюванні якості електронного навчання.

Результати. На основі огляду літератури про якість електронного навчання ми дійшли висновку, що якість електронного навчання не можна розглядати лише 3 точки зору студента, а з точки зору всіх учасників процесу електронного навчання. Окрім педагогічних аспектів, слід також враховувати організаційні, економічні та правові аспекти. Які виміри є ключовими для вимірювання якості електронного навчання, залишається питанням, на яке слід відповісти.

Висновки. Якість електронного навчання залежить від багатьох факторів. Незважаючи на багато дискусій щодо якості та пошук відповідних вимірів якості в електронному навчанні, досі не існує єдиного оціночного стандарту. Через це терміново потрібні ефективні якісні показники для електронного навчання.

Ключові слова: електронне навчання, якість, вища освіта, ІКТ, практики управління. 
Introduction. The quality of education is a widely used phrase at present. This quality can be seen differently in conjunction with knowledge, information, and educational technologies. These can be considered a catalyst for change in education, where the goal of our efforts is reforming and modernizing education for our knowledge-based society. One part of the effort is devoted to the special issues of quality of e-learning, which is seen as a potential tool for changes in education (Misut et al., 2014). As the integration of information and communication technologies (ICT) in modern educational activities creates alternative study paths, e-learning has become one of the most prominent concepts within the higher education institutions of today. E-learning has become a particularly attractive educational method, as the use of web-based tools reduces the costs of sharing vast amounts of data, reduces communication barriers and geographical distances, increases academic mobility in higher education, provides people with disabilities to have better access to higher education, and allows smaller institutions to gain international visibility through study programs online. Elearning nonetheless faces certain challenges. As e-learning is dependent on ICT as the primary teaching and learning tool, a prerequisite for an effective e-learning process is that learners have sufficient ICT skills, and program providers have sufficient professional competence and adequate educational strategies to manage distance programs with the help webbased tools (Luchaninova et al., 2019). Thus, it should be emphasized that e-learning is efficient only if it the learning content is updated regularly, and the teaching methodology used in the distance programs helps the learners master the learning material and acquire knowledge. In short, e-learning must respond to its stakeholders' needs.

We can start with the question what is excellent education? And is the quality of traditional face-to-face education different from the quality of e-learning? What are the determinants of quality and who is to judge whether education is excellent or not? On the one hand, we have national agencies that set external quality standards, and on the other hand, consumers who have certain expectations and criteria based on which they judge whether a certain educational experience is of sufficient quality or not. The views of both can also differ, and the common denominator for all is that the educational organization must, on the one hand, meet the quality standards set by national quality agencies in education and, on the other, not only meet but also exceed the expectations of its consumers. Therefore, the quality of education must be addressed (measured and managed) comprehensively, which means that in addition to pedagogical quality, it is also necessary to address market quality. Therefore, a distinction must be made between quality that meets specifications (standard quality) and quality that meets expectations.

Review of Quality in education. Quality has always been a prime concern in education and hence numerous studies related to quality and education have been conducted across the world. E-learning quality is a complex and multi-faceted issue. Some argue that the quality of e-learning should be judged by the same criteria and standards as face-to-face education. Others hold that conventional qualitative concepts are not appropriate because e-learning is so structurally different (E-learning Advisory Group 2002; Stella and Gnanam 2004). Yet others argue that, while certain general principles of quality should apply to both conventional and e-learning, there are certain features unique to e-learning that should also be addressed, such as asynchronous interactions, open access to vast resources, and distributed learning (Jung 2008). Furthermore, e-learning typically relies to a greater extent than conventional education on learners' motivation and commitment to interactivity and collaboration, which make it more difficult to gauge and assure the quality of e-learning.

Quality in education is one of the main issues examined by modern scholars and practitioners who operate on the international education and resources market. High quality is an extremely important factor for competitiveness (Adamišin, Vavrek, Pukala, 2015). In today's competitive environment, the management and staff of educational institutions should efficiently manage the learning process, and take steps to improve their institutions' competitiveness level, all of which is impossible if no steps are taken to improve quality in education. 
The quality of education reflects the relationship between learning (seen as a result, a process or as an education system) and the demands, goals, standards (regulations) and requirements set by individuals, businesses, organisations, local community members, and the state at large. If we use the above approach, the term 'quality of education' should be broken down into the following terms that require a separate definition each (Rubin, 2010):

- Quality of teaching (learning process design, teaching methodology).

- Quality of academic staff.

- Quality of study programs.

- Quality of equipment, maintenance, and support rendered, qualitative characteristics of the learning environment.

- Characteristics of students, school students, university entrants.

- Quality of university management.

- Quality of research.

The quality of e-learning is the leading motive in educational policy, a requirement for providers and the expectation of consumers (students). Quality is a concept that is not characterized by a precise definition, but by a positive connotation. Ehlers and Pawlowski (2006) have argued that quality in e-learning brings together the fields of education, technology, and economy in comprehensive concepts in order to contribute to societal development, to innovate formal, non-formal, and informal learning opportunities, and empower learners as citizens for participation. McLoughlin and Lee (2008) stress that the challenges of e-learning in a networked society mainly concern the meaning of the three Ps: personalization, participation, and productivity. These authors have stated that these dimensions are crucial for successful e-learning, that is, the individual's prerequisite motives and motivation (personalization), the individual's participation in the learning process (participation), and the individual as a co-producer in the e-learning process (productivity). The perception of quality is thus influenced by a wide range of arguments (criteria or indicators), but also by beliefs (Ehlers, 2007).

The quality of e-learning is necessarily hinged on the quality of its components: learning content, subject implementation (from implementation planning to implementation and evaluation), and technology that supports pedagogical processes (Lapuh Bele \& Rozman, 2007). High-quality learning content plays an important role, as learning content is a fundamental learning resource in distance learning. Excellent online learning content is not comparable to traditional printed materials, as it is interactive (allows consumer inputs and responds to them), multimedia-enriched (static images, diagrams, screenshots, animations, simulations, audio recordings) and allows participants to evaluate their acquired knowledge (questions and knowledge testing tests with knowledge and performance feedback).

Planning and then implementation itself are also extremely important. It is necessary to plan in the context of the study program and individual study subject, and to provide for the period and time for such subject's implementation, including activities, learning materials, and learning forms. During the course, the mentor guides and directs learning. The tutor encourages social contacts, motivates the participants, and forwards any questions and problems to those responsible (lecturer, organizer, technical service). Without a significant human factor, the chances of achieving the goals are very small.

The third component is technology and the solutions derived from it. The usability, accessibility and friendliness of the portal or platform, are a necessary basis for successful education.

In e-learning, communication and collaboration are not physical, but take place through ICT. According to many authors, student-centeredness is key to student satisfaction (Achtemeier et al., 2003; Ardito et al., 2006; Holzinger, 2005; Squires \& Preece, 1999). Student-centered learning puts the student at the center of the learning process. This means that students' needs, requirements, prior knowledge, abilities, and limitations are taken into consideration when planning curricula. Based on these findings, we also include different learning strategies, learning styles, experiences, and motivations. The student-centered paradigm also includes evaluation and process improvement (Notess, 2001). 
Taking this paradigm into account, we try to influence the improvement of student satisfaction, and thus also influence the motivation for and effectiveness of learning.

Laurillard (2002) finds that active learning, feedback, and reflection are important steps in acquiring knowledge. If we also consider Piaget's findings on the construction of knowledge, we can conclude that successful learning requires continuous consolidation of knowledge and continued re-learning of the acquired knowledge. We can support this strategy with correct course planning and by learning content that enables real-time assessment of knowledge and immediate feedback, and its implementation is enabled by technology.

Barron (2006) presents ten secrets of effective e-learning:

- a shared vision of student focus shared by all stakeholders in the process;

- an in-depth plan for the implementation of the course, based on the proposal, which includes the structure, form, and expectations regarding the content, and the mentor prepares it individually and considering the results of the evaluation of previous implementations;

- knowledge testing and feedback on the achieved level of knowledge, quantitatively and qualitatively;

- group work and collaborative learning;

- effective leadership and guidance, which can only be provided by properly motivated and trained mentors,

- $\quad$ staff training and support, which ensures expertise on technology and appropriate didactic approaches, and provides counseling and other support services,

- clearly expressed expectations, which include deadlines for completion of activities and consequences of delays, structures, and forms of submitted student work, rules of conduct in the course, expected level of participation and involvement, clearly communicated consequences of "intellectual property theft";

- meaningful feedback with which the student receives honest and positive information about their work;
- monitoring and evaluation provided to the administration and the mentor by the learning platform and recorded data;

- continuous improvement based on summative and formative evaluation.

The importance and necessity of feedback in e-learning is emphasized by many researchers and practitioners. Barron (2006) points out that, in addition to the quantitative result obtained from summative evaluation (for example, obtained through knowledge tests), students also expect substantive feedback that is not given automatically but is given by a living teacher. Barron says, "students fiercely agree in their desire for quick, accurate, and meaningful feedback." Students need both group and personal feedback.

The European Universities Association's 2006 report (Ehlers, 2007) is important in ensuring the quality of e-learning. Based on this report, Ehlers (2007) highlights a culture of quality that depends on two factors:

$\square$ quality management: a technocratic element that provides tools and mechanisms for measuring, evaluating, assuring, and improving quality;

$\square$ commitment to quality: a cultural element that is important both at the level of individuals and at the level of groups.

Ehlers (2004) finds that students' perceptions of the quality of e-learning are influenced by factors that classify them into the following seven groups: lecturer support, participation, technology, expectations and benefits, pre-implementation information, course structure, subject, and didactics. However, the quality of e-learning cannot be viewed only from the student's perspective, but from the point of view of all participants in the e-learning process (Ehlers, 2007), that is, also from the point of view of the founders, school owners, management, supervisory bodies, lecturers and other employees, and employers who employ graduates. In addition to pedagogical aspects, organizational, economic, and legal aspects must also be considered. 
Ossiannilsson \&Landgren (2012) conducted a study on quality in e-learning, emphasizing the increase in knowledge regarding the ways in which quality should be evaluated in the context of a quality assurance system. Thus, e-learning should be included as a natural part of any evaluation. Through an analysis of development, research, and networking on an international basis, an evaluation model was developed, namely the e-learning quality model. This includes ten quality aspects (which, in turn, include several indicators).

These quality

material/content, aspects are environment, communication, cooperation and interactivity, student assessment, flexibility and adaptability, support (student and staff), staff qualifications, vision and institutional leadership, resource allocation, and the holistic and procedural aspect.

This report states that e-learning must be assessed from a holistic perspective, that is, all ten aspects outlined earlier must be considered to an equal extent. Another conclusion is that if a national authority/organization is to evaluate e-learning, quality indicators are not enough. The evaluating authority will need to develop and adapt its own working methods and ensure its own competence.

We can conclude that there is no single definition of quality in education and even less in e-learning, and the fact is that the quality of services is not only important when the consumer is confronted with the service, but in some cases may affect the quality of life in the future (Fitzsimmons J. \& Fitzsimmons M., 1998, p. 274; Pukala, 2018). This definition is certainly important for education, as due to the nature of the service (higher education, diploma) the consumer expects the consequent effects to manifest in their life (e.g., better job, higher income, promotions, higher reputation in the job market, etc.).

It can happen that the consumer attributes high quality to the course of the service, and if expectations go unmet (for example, if nothing changes in the business area in his life), the consumer can attribute the low quality to the result. Precisely because of this, quality in educational institutions must be the subject of measurement, both during the implementation itself and immediately after the end of the training and after a certain period, when the participant has already completed the training.

The literature provides several models, frameworks, and recommendations for quality assurance in e-learning (e.g. Marshall, 2012; Masoumi \& Lindström, 2012; Saatz \& Kienle, 2013; Udo et al., 2011; Zhang \& Cheng, 2012) The fact that the quality principles of successful technology-supported learning are the same as those in a traditional classroom should not be overlooked. According to this, the fundamental requirement is that well-designed learning activities will ensure success regardless of the means (technology). It must be said that elearning is not just another way of implementation of traditional teaching, but it is a new approach to education. The methods of quality assurance must take this fact into account (Misut et al., 2014).

E-learning quality dimensions and measuring. In the quality of services, which also includes e-learning, the emphasis is primarily on customer satisfaction. In service activities, however, consumers often must actively participate in the provision of the service themselves, and such cooperation must be properly encouraged and guided.

For this reason, it is very important to find or know the factors that cause consumer satisfaction. The term dimension of quality is often used in this context. Instead of trying to find a good set of definitions, it makes sense to focus on the dimensions that make up quality and reach some social consensus on these. Scientists are trying to define the dimensions of quality, especially in relation to services. Table 1 compares the dimensions of service quality by different authors. If service quality is generally defined as the difference between expected and perceived quality, Hackman et al. (2006) find that parallel definitions can be found in the relevant e-commerce literature. 
Table 1. Comparison of service quality dimensions of different authors

\begin{tabular}{|l|l|l|l|}
\hline Garvin (1991) & $\begin{array}{l}\text { Berry, Parasuraman in } \\
\text { Zeithaml (1985) }\end{array}$ & $\begin{array}{l}\text { Zeithaml, Parasuraman } \\
\text { in Berry (1990) }\end{array}$ & Grönroos (2000) \\
\cline { 1 - 2 } operation & tangible & tangible & technical suitability \\
\hline characteristics & reliability & reliability & functionality \\
\cline { 1 - 2 } reliability & responsiveness & responsiveness & environment \\
\cline { 1 - 2 } compliance & competence & & \multirow{2}{*}{ price } \\
\cline { 1 - 2 } durability & courtesy & & \\
\cline { 1 - 2 } competence & credibility & \multirow{2}{*}{ consumer orientation } & \\
\cline { 1 - 2 } aesthetics & security & & \\
\cline { 1 - 2 } perceived quality & accessibility & & \\
\cline { 1 - 2 } & communicativeness & & \\
\cline { 1 - 2 } & consumer understanding & & \\
\hline
\end{tabular}

Source: Garvin (1991); Berry et al. (1985); Zeithaml et al. (1990); Groonros (2000).

Based on an extensive review of the literature in the field of e-service quality Zeithaml et al. (2002) combine past work into five main dimensions: data availability and content, ease of use, privacy/security, graphics, and compliance/reliability. They also mention fewer researched criteria such as responsiveness and personalization.

The defined dimensions of the quality of e-services are also an important contribution to the field of e-learning, although the authors do not specifically mention it. We believe that by appropriately modifying the defined dimensions, we can successfully measure the quality of e-learning services. The dimensions of Zeithaml can be applied to e-learning. Data availability and content are certainly very important dimensions.

The consumer (participant) of e-learning needs all the information regarding online education: schedule, notification system, eindex, possibility to register and unsubscribe from exams, study material, links to additional study content, communication possibilities with other participants, lecturers, organizers education (forums, chat rooms, personal messages, etc.), the possibility of testing knowledge, etc., all of which must be accessible at anytime from anywhere, as long as the consumer has an internet connection.
Ease of use is also important in e-learning. The consumer must access the desired content in an easy way. The website must be designed to be transparent and easy to use.

Communication with the educational organization must also be easy. Assuming that e-learning is chosen by people who have a home far away from the educational organization or whose daily obligations do not allow them to attend lectures in the afternoon, we must also simplify other processes, such as administrative, which are otherwise personally regulated by the consumer, so you can edit them online. Privacy/security is a dimension that should not be neglected. Consumers need to feel safe in an e-learning environment; their assessments are personal data, as well as taking knowledge tests; their personal messages are visible only to them; the consumer must have a choice of what data and content they share with the virtual community and which are visible only to them. Of course, the educational organization must also comply with the Personal Data Protection Act in this regard. The graphic image is defined as a dimension by many authors, but it is otherwise named (for example aesthetics) and is certainly important, as the website to be accessed must have an attractive appearance especially learning materials must follow the guidelines of modern online learning. 
Compliance/reliability is the fulfilment of requirements for updating web pages, both in terms of notifications and updating of web materials and links to other web resources. We believe that responsiveness and personalization are also important dimensions in e-learning. Regarding personalization, consumers want the website to come to them with a username and password, to remember to offer them the continuation of their studies, and to remind them of any unfulfilled obligations, etc.

Responsiveness is also an important dimension, as consumers want quick feedback, both from lecturers and other professional staff or management of the educational organization, as well as quick resolution of any technical problems that may arise due to the use of information technology. Based on the dimensions of service quality, many authors have proposed dimensions of e-learning quality, as education, in all its characteristics, belongs to the service business and must also consider marketing principles and findings in its successful operation. A comprehensive overview of the dimensions of quality in elearning is shown in Table 2.

\section{Table 2. Dimensions of Quality in e-learning}

\begin{tabular}{|c|c|}
\hline Approach & Dimensions of Quality \\
\hline Phipps \& Merisotis (2000) & $\begin{array}{l}\text { 1) institutional support 2) course development 3) teaching and learning } \\
\text { 4) course structure 5) student support } \\
\text { 6) faculty support 7) evaluation and assessment }\end{array}$ \\
\hline Sloan-Consortium (2010) & $\begin{array}{l}\text { 1) institutional support 2) course development and instructional design } \\
\text { 4) course structure 5) teaching and learning 6) social and student engagement } \\
\text { 7) faculty support 8) student support 9) evaluation and assessment }\end{array}$ \\
\hline $\begin{array}{l}\text { National Education Association } \\
(2002)\end{array}$ & $\begin{array}{l}\text { 1) curriculum 2) instructional design 3) teaching quality } \\
\text { 4) student role 5) assessment 6) management and support systems 7) technical } \\
\text { infrastructure }\end{array}$ \\
\hline Ron Oliver (2001) & $\begin{array}{l}\text { 1) teacher expertise 2) student readiness } 3 \text { ) technology infrastructure } \\
\text { 4) reusable learning objects 5) reusable learning design }\end{array}$ \\
\hline $\begin{array}{l}\text { The Higher Learning } \\
\text { Commission }(\mathrm{s} / \mathrm{d})\end{array}$ & $\begin{array}{l}\text { 1) institutional context and commitment 2) curriculum and instruction } \\
\text { 3) faculty support 4) student support } \\
\text { 5) evaluation and assessment }\end{array}$ \\
\hline $\begin{array}{l}\text { Sloan-C Consortium's } 5 \text { Pillars } \\
\text { (Lorenzo \& Moore, 2002) }\end{array}$ & $\begin{array}{l}\text { 1) learning effectiveness 2) cost effectiveness 3) access } \\
\text { 4) faculty satisfaction 5) student satisfaction }\end{array}$ \\
\hline Sangrà, et al. (2002) & $\begin{array}{l}\text { 1) learning support services 2) learning delivery services } \\
\text { 3) learning development 4) teaching capability 5) evaluation 6) accessibility } \\
\text { 7) technical capability 8) institutional capability }\end{array}$ \\
\hline McGorry (2003) & $\begin{array}{l}\text { 1) flexibility 2) responsiveness and support 3) self-reported (perceived) learning 4) } \\
\text { Interaction-participation in learning 5) perceived usefulness and ease of use of } \\
\text { technology } \\
\text { 6) technical support 7) student satisfaction }\end{array}$ \\
\hline Fresen $(2005,2007)$ & $\begin{array}{l}\text { 1) institutional factors 2) technology factors 3) lecturer factors 4) student factors 5) } \\
\text { instructional design factors } \\
\text { 6) pedagogical factors }\end{array}$ \\
\hline $\begin{array}{l}\text { Swedish National Agency of } \\
\text { Higher Education (2008) }\end{array}$ & $\begin{array}{l}\text { 1) material/content 2) structural/virtual environment } \\
\text { 3) communication, cooperation, and interactivity 4) student assessment } \\
\text { 5) flexibility and adaptability 6) support (student and staff) 7) staff qualifications } \\
\text { and experience 8) vision and institutional leadership 9) resource allocation 10) the } \\
\text { holistic and process aspect }\end{array}$ \\
\hline $\begin{array}{l}\text { Holsapple \& Lee-Post (2006; } \\
\text { Lee-Post, 2009) }\end{array}$ & $\begin{array}{l}\text { 1) system quality 2) information quality 3) service quality } \\
\text { 4) use and user satisfaction 5) net benefits }\end{array}$ \\
\hline
\end{tabular}




\begin{tabular}{|c|c|}
\hline Approach & Dimensions of Quality \\
\hline Khan and Granato (2008) & $\begin{array}{l}\text { 1) pedagogical 2) technological 3) interface design } \\
\text { 4) evaluation 5) management 6) resource support 7) ethical 8) institutional }\end{array}$ \\
\hline $\begin{array}{l}\text { The E-learning Maturity Model } \\
\text { (Marshall \& Mitchell, 2004; } \\
\text { 2007) }\end{array}$ & $\begin{array}{l}\text { 1) learning 2) development 3) support 4) evaluation } \\
\text { 5) organization }\end{array}$ \\
\hline Zhao (2003) & $\begin{array}{l}\text { 1) course effectiveness 2) adequacy of access in terms of technology infrastructure } \\
\text { 3) student satisfaction 4) academic satisfaction (teaching staff) }\end{array}$ \\
\hline Mahony et al (2009) & $\begin{array}{l}\text { 1) technological environment 2) constructive alignment } \\
\text { 3) communication and transactional presence 4) student satisfaction 5) risk } \\
\text { management }\end{array}$ \\
\hline Barker (Barker, 1999) & 1) inputs and resources 2) processes and practices 3) outputs and outcomes \\
\hline Chickering and Ehrmann (1996) & $\begin{array}{l}\text { 1) contact between students and faculty 2) reciprocity and cooperation among } \\
\text { students 3) active learning techniques } \\
\text { 4) prompt feedback 5) time on task 6) high expectations } \\
\text { 7) respect diverse talents and ways of learning }\end{array}$ \\
\hline Cohen and Ellis (2004) & $\begin{array}{l}\text { 1) community of learners 2) instructor accessibility 3) class organization } \\
\text { 4) "feel" of the class 5) peer impact }\end{array}$ \\
\hline Volery and Lord (2000) & $\begin{array}{l}\text { 1) technology (ease of access and navigation, interface design and level of } \\
\text { interaction) 2) the instructor (attitudes towards students, instructor technical } \\
\text { competence and classroom interaction) 3) the previous use of the technology from a } \\
\text { student's perspective }\end{array}$ \\
\hline Yeung (2002) & $\begin{array}{l}\text { 1) institutional support 2) course development } \\
\text { 3) teaching/learning process 4) course structure 5) student support 6) faculty support } \\
\text { 7) evaluation and assessment }\end{array}$ \\
\hline Donabedian (1980) & $\begin{array}{l}\text { 1) prerequisites (input or structure) 2) learning process } \\
\text { 3) result (output or outcome) }\end{array}$ \\
\hline Ehlers (2004) & $\begin{array}{l}\text { 1) tutor support 2) collaboration 3) technology 4) costs-expectations-benefits } \\
\text { 5) information transparency of provider/course 6) course structure 7) didactics }\end{array}$ \\
\hline $\begin{array}{l}\text { Ehlers, Goertz, Hildebrandt, \& } \\
\text { Pawlowski (2005) }\end{array}$ & 1) knowledge 2) experience 3) design 4) analysis and criticism \\
\hline Frydenberg (2002) & $\begin{array}{l}\text { 1) institutional or executive commitment, organization, and structure of an e- } \\
\text { learning services developer and/or provider 2) technological infrastructure } \\
\text { 3) students' services 4) design and development of e-learning programs and courses } \\
\text { 5) program delivery 6) structures to support financial management and ensure } \\
\text { financial health 7) regulatory and local compliance 8) evaluation processes }\end{array}$ \\
\hline ICCA (2004) & $\begin{array}{l}\text { 1) supplier 2) teaching, training, and mentoring 3) content management 4) learning } \\
\text { and development process management 5) content relevance } 6 \text { ) design process } \\
\text { 7) pedagogy 8) working and learning environment 9) learner preparation. }\end{array}$ \\
\hline EFQM Excellence Model (2003) & $\begin{array}{l}\text { 1) leadership 2) people 3) policy and strategy 4) partnerships and resources } \\
\text { 5) processes 6) people results 7) customer results 8) society results 9) key } \\
\text { performance results }\end{array}$ \\
\hline Pawlowski (2003) & $\begin{array}{l}\text { 1) strategic planning 2) framework/program 3) cooperation 4) course development } \\
\text { 5) marketing 6) realization 7) student support 8) teacher/developer support 9) central } \\
\text { database } \\
\text { 10) evaluation }\end{array}$ \\
\hline $\begin{array}{l}\text { European Committee for } \\
\text { Standardization (2006) }\end{array}$ & 1) general 2) context of usage 3) experience 3) method of quality approach \\
\hline
\end{tabular}




\begin{tabular}{|l|l|}
\hline \multicolumn{1}{|c|}{ Approach } & \multicolumn{1}{c|}{ Dimensions of Quality } \\
\hline E-xcellence (EADTU, 2007) & $\begin{array}{l}\text { 1) strategic management 2) curriculum design 3) course design 4) course delivery 5) } \\
\text { staff support 6) student support }\end{array}$ \\
\hline ICCA (2004) & $\begin{array}{l}\text { 1) learner preparation 2) supplier 3) teaching, training, and mentoring } \\
\text { 4) content management 5) learning and development process management } \\
\text { 6) content relevance } \\
\text { 7) design process 8) pedagogy 9) working and learning environment }\end{array}$ \\
\hline $\begin{array}{l}\text { Meca-ODL (Francés \& Borona, } \\
\text { 2002) }\end{array}$ & $\begin{array}{l}\text { 1) conception 2) analysis 3) design 4) content 5) production 6) delivery } \\
\text { 7) evaluation }\end{array}$ \\
\hline $\begin{array}{l}\text { QUAL-E-LEARNING (Francés, } \\
\text { 2004; 2004) }\end{array}$ & $\begin{array}{l}\text { 1) context 2) legal framework 3) pedagogy 4) technology } \\
\text { 5) evaluation 6) certification }\end{array}$ \\
\hline $\begin{array}{l}\text { QSEL (Lodzinski \& Pawlowski, } \\
\text { 2006, p. 113) }\end{array}$ & $\begin{array}{l}\text { 1) policy and strategy 2) management 3) resources } \\
\text { 4) processes 5) learner-orientation 6) staff management and contentment } \\
\text { 7) outward appearance/innovation 8) results }\end{array}$ \\
\hline $\begin{array}{l}\text { Quality Adaptation Model } \\
\text { (European Committee for } \\
\text { Standardization, 2006b; } \\
\text { Pawlovski 2006) }\end{array}$ & $\begin{array}{l}\text { 1) vision 2) policy and strategy 3) awareness 4) objectives 5) actors 6) methods and } \\
\text { instruments 7) measures indicators 8) activities 9) participation 10) use and } \\
\text { utilization }\end{array}$ \\
\hline $\begin{array}{l}\text { SEEQUEL (Dondi, 2004a, } \\
\text { 2004b, 2006) }\end{array}$ & \begin{tabular}{l} 
1) learning sources 2) learning processes 3) learning context \\
\hline
\end{tabular}
\end{tabular}

Source:: https://www.slideshare.net/rosariocacao/dimensions-of-quality-in-elearning

As can be seen, different authors cite different, albeit comparable, dimensions of elearning quality, where it can be seen that many of the proposed dimensions of elearning quality derive from the most popular service quality measurement methodologies, such as SERVQUAL and SERVPERF.

The SERVQUAL model (abbreviated from service quality), developed by Parasuraman, Berry, and Zeithaml (1988), is based on a comparison of consumer expectations and perceptions. The purpose of the model is to capture the consumer's overall perception of service quality (Parasuraman et al., 1994).

The SERVPERF methodology, which is based solely on measuring consumer perception (Cronin and Taylor 1992), is recognized as a better measuring instrument to measure the quality of services where the quality of service itself requires greater consumer involvement. (Lewlyn et al. 2011).

Although SERVPERF has a strong influence in the field of service quality and becomes a general measure of service quality, it is not entirely an appropriate instrument for assessing perceived quality in education (Abdullah, 2006).
The question of which instrument to use to measure quality in education therefore remains open.

Abdullah (2006) developed the HEdPERF (Higher Education PERFormanceonly) instrument for measuring quality in education based on the SEVPERF instrument. It identifies five dimensions of the quality of education, for which 38 variables have been developed: non-academic quality, which includes elements that enable students to fulfil their study obligations and relates to the tasks performed by non-academic staff; academic quality relating to the responsibilities of academic staff; availability, which includes elements relating to ease of contact, accessibility and convenience; study programs that include an element of importance of a wide range of reputable study programs and the possibility of specialization by adapting content; reputation, which is the responsibility of educational institutions to achieve a professional reputation in the public. In shaping the dimensions, Abdullah (2006) takes the position that the primary consumers are students, which is also, in our opinion, an advantage over other instruments in terms of measuring quality in education. 
Like the already mentioned measuring instruments, HEdPERF has received a lot of criticism. Some researchers argue that such an approach raises concerns about the lack of generalizability, but interestingly, as a technique, it precisely eliminates the problems associated with the effects of different activities.

Since information and communication technology is also included in the process in e-learning, it is necessary to add something else to the existing dimensions when designing a methodology for measuring quality in e-learning.

In the business world, Parasuraman, Zeithamlova, and Malhotra (2005) develop a methodology for measuring electronic services based on eleven dimensions, and later the final ES-QUAL (e-service-quality) scale is created by analysing the main components, consisting of 22 statements in four dimensions:

- Efficiency: ease and speed of access and usability of the website.

- Fulfilment: the extent to which delivery and availability promises are fulfilled.

- System availability: proper technical operation of the website.

- Privacy: the degree to which the website is secure and protects consumer information.

The same authors continued their work following the same procedure and developed the revised E-S-QUAL scale (E-RecSQUAL), consisting of eleven statements in three dimensions (Parasuraman et al., 2005):

- Responsiveness: effectively deal with problems and return to the site;

- Compensation: the degree to which a website compensates for consumer problems;

- Contact: availability of help by phone or on-line representatives.

The question, however, is to what extent these instruments are appropriate for measuring the quality of e-learning. Because of this dilemma and the need to develop an instrument to measure the quality of online education, Shaik et al. (2006) with the development of the DL-sQUAL scale (Distance Learning service Quality). However, this instrument does not yet have some general recognition.

Conclusions. A distance-learning course is defined as a subject taught in a remote mode using information technologies. The quality assessment question of distance learning courses is relevant to any teaching institution. To attract more students, the teaching process must be of a high quality.

Thus, the quality of a distance learning course depends on many factors, which must be evaluated by experts. The demand for elearning in education is rising, competition is increasing, and universities are investing significant resources towards improving the quality of their e-learning programmes.

Because of this, effective quality measures for e-learning are urgently required.

Many attempts have been made to establish quality standards for e-learning. The Joint Information Systems Committee (JISC), United Kingdom, has tried to establish effective practices with e-learning. The European Foundation for Quality in elearning (EFQUEL) has developed a label for quality e-learning, "UNIQUe." Kidney et al., (Cited in Ivanaj et al., 2019) identified eight quality assurance strategies: web development, editing, usability and accessibility, maintainability, copyright, infrastructure impact, content, and rigor. Despite these attempts, there is not yet a wellestablished and commonly accepted standard to measure e-learning quality. As MacDonald \& Donio (2007) underscored, "It is imperative that universities come to some kind of agreement regarding procedures and policies for quality standards in e-learning." Elearning development and marketing have not ceased to progress despite the absence of elearning quality standards. Therefore, many questions remain about the integrity and quality of e-learning. It is necessary to await a long track record of successes and failures before identifying the best standards for measuring the quality of e-learning. 


\section{REFERENCES}

1. Abdullah, F. (2006). Measuring Service Quality in Higher Education: Three instruments compared. International Journal of Research \& Method in Education 29:71-89. https://doi.org/10.1080/01406720500537445

2. Achtemeier, S. D., Morris, L. V., \& Finnegan, C. L. (2003). Considerations for developing evaluations of online courses. Journal of Asynchronous Learning Networks (JALN), 7(1), 1-13.

3. Adamišin, P., Vavrek, R., \& Pukala, R. (2015). Cluster analysis of Central and Southeast Europe via selected indicators of sustainable development. Environmental Economics, Education and Accreditation in Geosciences: Ecology, Economics, Education and Legislation, 135-140.

4. Ardito, C., Costabile, M. F., De Marsico, M., Lanzilotti, R., Levialdi, S., Roselli, T., \& Rossano, V. (2006). An Approach to Usability Evaluation of e-learning Applications. Universal access in the information society, 4(3), 270-283.

5. Barron, J. (2006). Top ten secrets of effective e-learning. Industrial and commercial training, 38(7), 360-364.

6. Cronin, J. J., \& Taylor, S. A. (1992). Measuring service quality: a re-examination and extension. Journal of Marketing, 56, 55-68.

7. Ehlers U.-D. \& Pawlowski J. (2006). Quality in European e-learning: an introduction. In Handbook on Quality and Standardisation in E-learning (eds U.-D. Ehlers \& J. Pawlowski), pp. 113. Springer, Berlin, Germany.

8. Ehlers, U. D. (2004). Quality in e-learning from a Learner's Perspective. Retrived February 27, 2021 from http://www.eurodl.org/materials/contrib/2004/Online_Master_COPs.html

9. Ehlers, U. D. (2007). Quality Literacy - Competencies for Quality Development in Education and e-learning. Educational Technology \& Society, 10(2), 96-108.

10. E-learning Advisory Group. (2002). Highways and pathways: Exploring New Zealand's elearning opportunities. Retrieved January 14, 2021, from http://cms.steo.govt.nz.

11. Fitzsimmons, J. A., \& Fitzsimmons, M. J. (1998). Service Management. Boston: McGrawHill.

12. Garvin, D. A. (1991). Barriers and gateways to learning. Education for judgment: The artistry of discussion leadership, 3-13.

13. Holzinger, A., \& Motschnig, R. (2005). Considering the Human in Multimedia: Learner Centered Design (LCD) \& Person Centered e-learning (PCeL). ISSEP 2005 Conference, University of Klagenfurt.

14. Ivanaj, S., Nganmini, G. B., Antoine, A. (2019). Measuring E-Learners' Perceptions of Service Quality. Journal of Organizational and End User Computing (JOEUC) 31(2). https://doi.org/10.4018/JOEUC.2019040105

15. Jung, I. S. (2008). Quality assurance and continuous quality improvement in distance education. In T. Evans, M. Haughey, \& D. Murphy (Eds.), International handbook of distance education (pp. 609-624). London: Emerald Group Publishing Limited.

16. Lapuh Bele, J., Bele, D., \& Rozman, D. (2007). Naj bo slika vredna tisoč besed? V V. Rajkovič, T. Urbančič, \& M. Bernik (ur.). Vzgoja in izobraževanje v informacijski družbi: zbornik 10. mednarodne multikonference Informacijska družba IS 2007, 12. oktober 2007 (str. 236-243). Ljubljana: Ministrstvo za šolstvo in šport; Institut Jožef Stefan; Zavod Republike Slovenije za šolstvo; Kranj: Fakulteta za organizacijske vede.

17. Laurillard, D. (2002). Rethinking University Teaching. A conversational framework for the effective use of learning technologies. London: Routledge.

18. Lewlyn, L.R., Barkur, G., Varambally, K.V.M., Motlagh, F.G. (2011). Comparison of SERVQUAL and SERVPERF metrics: an empirical study. TQM Journal, 23(6), 629-643.

19. Luchaninova, O., Koval, V., Deforzh, H., Nakonechna, L. \& Golovnia, O. (2019). Formation of communicative competence of future specialists by means of group work. Espacios, $40(41), 11$. 
20. MacDonald, C. \& Donio, J. (2007). Sharing e-learning Evaluation and Quality Measurement Resources. In R. Carlsen, K. McFerrin, J. Price, R. Weber \& D. Willis (Eds.), Proceedings of SITE 2007--Society for Information Technology \& Teacher Education International Conference (pp. 882-889). San Antonio, Texas, USA: Association for the Advancement of Computing in Education (AACE). Retrieved March 10, 2021 from https://www.learntechlib.org/primary/p/24662/.

21. Marshall, S. (2012). Improving the quality of e-learning: lessons from the eMM. Journal of Computer Assisted Learning, 28(1), 65-78. https://doi.org/10.1111/j.1365-2729.2011.00443.x

22. Masoumi, D., \& Lindström, B. (2012). Quality in e-learning: a framework for promoting and assuring quality in virtual institutions. Journal of Computer Assisted Learning, 28(1), 27-41. doi: $10.1111 / \mathrm{j} .1365-2729.2011 .00440 . x$

23. McLoughlin C. \& Lee M.J.W. (2008) The three P's pedagogy for the networked society: personalisation, participation and productivity. International Journal of Teaching and Learning in Higher Education 20, 10-27.

24. Misut, M., Pribilova, K. (2014). Measuring of Quality in the Context of e-learning. Procedia - Social and Behavioral Sciences, 177, 312 - 319

25. Notess, M. (2001). Usability, User Experience, and Learner Experience. eLearn Magazine, Avgust, 2001. Retrived February 2021 15, from http://www.elearnmag.org/subpage.cfm?section=tutorials\&article=2-1

26. Parasuraman, A., Zeithaml, V. A., \& Berry, L. L. (1994). Reassessment of Expectations as a Comparison Standard in Measuring Service Quality: Implications for Further Research. Journal of Marketing, 58(11), 111-124.

27. Parasuraman, A., Zeithaml, V. A., \& Malhotra, A. (2005). E-S-QUAL: A Multiple-item Scale for Assessing Electronic Service Quality. Journal of Service Research, 7(3), 213-233.

28. Pukala R., Lysytsia N. M., Prytychenko T. I., Gron O. V. (2018). International Marketing of Economic Educational Services in Ukraine and Poland. Bussines Inform, 9, 77-84.

29. Rubin, Yuri. (2010). Modern E-learning: Qualitative education accessibility concept. Quality Assurance of E-learning. Retrived February 20, 2021 from https://www.enqa.eu/indirme/papers-and-reports/workshop-and-seminar/ENQA_wr_14.pdf

30.Saatz, I., \& Kienle, A. (2013). Increasing Quality in large scale University Courses. Eflashcards as an approach to support active learning and individual facilitation. Eleed, 9 (1). https://eleed.campussource.de/archive/9/3655

31. Shaik, N., Lowe, S., \& Pinegar, K. (2006). DL-sQUAL: A multiple-item scale for measuring service quality of online distance learning programs. Journal of Distance Learning Administration, IX(II). Retrived February 20, 2021 from http://www.westga. edu/ distance/ojdla/summer92/shaik92.htm

32. Squires, D., \& Preece, J. (1999). Predicting Quality in Educational Software: Evaluating for Learning, Usability and the Synergy between them. Interacting with Computers, 11, 467-483.

33. Stella, A., \& Gnanam, A. (2004). Quality assurance in distance education: The challenges to be addressed. Journal of Higher Education, 47(2), 143-160.

34. Udo, G. J., Bagchi, K. K., \& Kirs, P. J. (2011). Using SERVQUAL to assess the quality of e-learning experience. Computers in Human Behavior, 27(3), 1272-1283. https://doi.org/10.1016/j.chb.2011.01.009

35. Zhang, W., \& Cheng, Y. L. (2012). Quality Assurance in E-learning: PDPP Evaluation Model and its Application. The International Review of Research in Open and Distance Learning, 13(3), 66-82. https://doi.org/10.19173/irrodl.v13i3.1181 